\title{
Menata Langkah, Membentuk Ekosistem
}

\author{
Ismail Suardi Wekke \\ Dewan Pendidikan Kabupaten Maros \\ Email: iswekke@gmail.com
}

Assalamu Alaikum Warahmatullahi Wabarakatuh

Yth. Bapak/Ibu, Saudara/Saudari

Alhamdulillah, kita memasuki Februari 2022. Pada Maret yang akan datang menapaki 100 hari Dewan Pendidikan Kabupaten Maros.

Sejauh ini, kita menjalani aktivitas bersama dalam kondisi yang tetap sesuai dengan koridor partisipasi masyarakat untuk pembentukan ekosistem pendidikan di Kabupaten Maros.

Selama Januari 2022, alhamdulillah telah berlangsung kegiatan sosialisasi akreditasi sekolah/madrasah. Begitu pula dengan diklat perpustakaan. Bahkan di bulan Februari ini juga telah terlaksana, dan selanjutnya Maret akan dilaksanakan kembali. Bahkan lebih dari satu kali, supaya semasa Ramadhan kita insya Allah fokus pada ibadah Ramadhan.

Sehingga target 12 kali diklat perpustakaan selama 2022 ini bisa terselesaikan insya Allah.

Bapak/Ibu, Saudara/Saudari...

Kita juga masih menanti adanya sekretariat, kalaulah kita tidak memungkinkan mendapatkan sekretariat di lokasi yang baru, sekretariat lama digunakan kembali juga akan sangat bagus. Berbanding harus mencari ke lokasi yang baru, sementara belum ada tempat yang dapat digunakan untuk itu.

Untuk Februari, insya Allah aktivitas yang sudah terjadwal antara lain:

1) KKN STAI DDI Maros di Kecamatan Tompobulu sudah berada di lokasi.

2) KKN UIN Alauddin Makassar di tiga kecamatan, akan berada di lokasi mulai besok insya Allah 14 Februari 2022.

3) "Belajar di Thailand" Sabtu, 19 Februari 2022, pukul 16.00-18.00 wita - Maros.

4) Kuliah Umum bersama CYS, Ibu Monika Raharti, Ph.D., pada tanggal 25 Januari 2022, Pukul 16.00-18.00 wita - Maros.

5) Adapun seminar bersama dengan Prof. Imam Suprayogo awalnya direncanakan Februari ini, hanya saja masih perlu dipersiapkan dengan lebih rapi, sehingga akan dilaksanakan insya Allah Maret 2022.

Terima kasih atas kerjasama, dukungan, dan partisipasi Bapak/Ibu, Saudara/Saudari.

Selamat berakhir pekan, dan semoga tetap sehat selalu.

Wassalam

Ismail Suardi Wekke 